\title{
Historein
}

Vol $3(2001)$

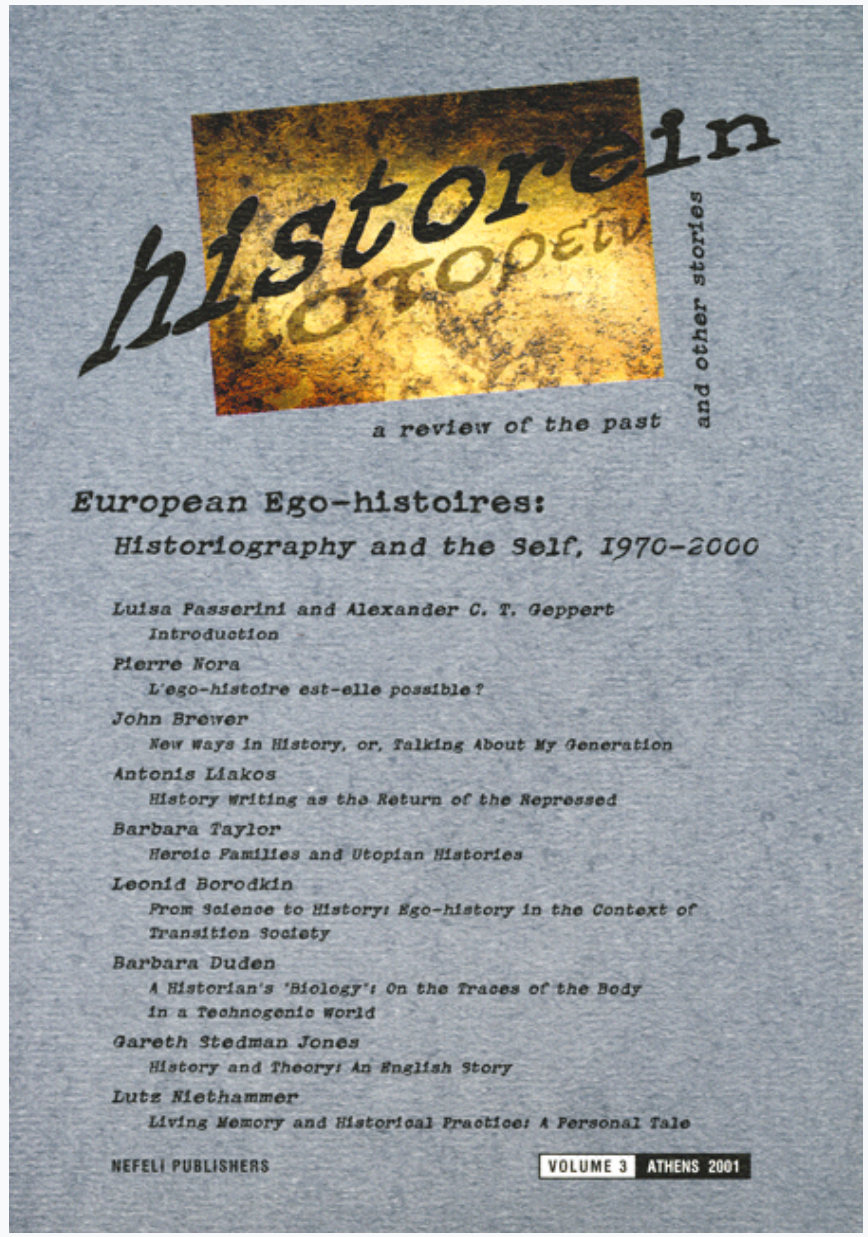

\section{History and Theory: An English Story}

Gareth Stedman Jones

doi: $10.12681 /$ historein.103

\section{Copyright @ 2012 , Gareth Stedman Jones}

\section{(9) $(\mathbb{Q} \Theta(-)$}

This work is licensed under a Creative Commons Attribution-NonCommercialShareAlike 4.0.

\section{To cite this article:}

Stedman Jones, G. (2002). History and Theory: An English Story. Historein, 3, 103-124. https://doi.org/10.12681/historein.103 


\section{History}

\section{and}

\section{Theory:}

\section{An English}

Story
I cannot say when I first decided that I wanted to be a historian. As far back as I can remember I liked old things - old books, old furniture, old houses, old streets, the lives of people in the past. A little later - in my teens - I formed a not very specific ambition to be a writer. It was not until later still that I decided in any explicit sense that I would be a historian. But the gravitation towards history was always there. In this sense, the choice was not difficult. History chose itself. I never imagined that I possessed the particular aptitudes or temperament of a poet or a novelist. In the case of poetry, it was not until I was an adult that I became aware how powerfully poetry could convey ideas. Novels involved too much intrusion, whether of myself or others: a too encompassing scrutiny of character; too much focus on the personal; too much transgression of the boundary between public and private. The process of assembling and constructing history was as creative a form of writing, but without these drawbacks, and from childhood onwards, history - all kinds of history - fascinated me. More prosaically, it was an academic subject I discovered I was good at. There may also have been negative reasons: as time went on, available alternatives became less attractive. In the 1960 s, I hoped to become a journalist, to become involved in the running of a left-leaning quality weekly. Our model at the time was France Observateur. But our efforts to launch such a paper in 1971 foundered fairly quickly and in the aftermath of the 1960s, entry into conventional journalism or party politics looked unappetising. A career as an independent author was another possibility, but I found myself illmatched to its demands. My inability to let go of a question until I had finally exhausted its meaning to my satisfaction, did not accord happily with a professional observance of deadlines and ensuring a reasonable income. 
All these considerations were no doubt important in guiding me towards history as a vocation. But I also think there was another reason which had less to do with my personal trajectory than with the society and culture in which I grew up. If, as is often said, great generals are not made in peacetime, it could also be said that great politics are not generally made when the main business is withstanding or managing decline. In a culture on the defensive, new ideas are yet another source of threat. For the friends of progress, the politics of post-imperial Britain have been for most of the time, if not disastrous, at best uninspiring, dispiriting or distasteful. To be a historian has been a way of retaining a larger perspective, of preserving a kind of spiritual freedom and of hanging onto something usually lost after youth - a curiosity about other countries, other cultures, other times beyond the demands of position or occupation. In the darkest years of Mrs Thatcher, a recurrent joke shared with my old friend and fellow historian, Raphael Samuel, was that if we could not change the world, we could at least aspire to understand it.

I was born on December 17th, 1942 and the world in which I was brought up - Britain of the 1940s and 1950s - was deeply different from the Britain you might visit today, or at least, the Britain of large towns and major cultural centres most accessible to visitors from abroad. This world was about to be submerged (but not obliterated) by the changes of the $1960 \mathrm{~s}$. As the poet, Philip Larkin, once famously proclaimed, "sexual intercourse" began in 1963 - a gnomic and somewhat bilious way of drawing a line between an old world and a new. This talk bears Larkin out. Since then, the changes which have occurred in Britain's conception of itself and its relation to the rest of the world have continued to be experienced as a major and unresolved problem in British politics. The national neurosis about Britain's relationship with Europe is only its most obvious manifestation. Living through these changes and in some ways attempting to embody them, but never without that sense of the unceasing undertow of a still potent past - however much a source of impatience and sometimes of anxiety - has never been less than a stimulant of the historical imagination.

The writing of good history is itself the product of particular historical conjunctures. The defeat of the Jacobite rebellion of 1745 and the stark contrast between Highland and Lowland society in eighteenth-century Scotland were two of the catalysts of the great conjectural histories of the Scottish Enlightenment from Hume and Smith to Ferguson and Millar. Contemporary Britain provides a less epic, more comic sense of the juxtaposition of past and present. Like AustriaHungary before the First World War, the contemporary United Kingdom is one of only two imperial monarchies - the other is Japan - to have survived into the new millennium. It provides ever-fertile ground for reflecting upon the "historic present." For it is hard to miss the bizarre contrast between the cheerful if nervous proclamation of a new Britain without a history amidst the louring presence - not just ideological, but also institutional - of an undead, scowling and sometimes vengeful imperial past. 
Let us be more specific about the changes I have in mind. The really important divide in modern British history was not, as you might expect, the death of Victoria in 1901, 1911 (the first PostImpressionist exhibition in Britain and Roger Fry's dating of the beginning of the modern world), or the World Wars of 1914-1918 and 1939-1945. Instead, it occurred at precisely the time I am talking about, in the early 1960s. ${ }^{1}$ To put the argument another way, there was more similarity between the 1870s and the 1950s than there is between the 1950s and now.

The First World War produced the enfranchisement of women, the emergence of labour and the end of the gold standard. But the basic trends in British society continued to be those first established around the 1870s. The prevailing demographic pattern and its attendant family values, involving clearly demarcated sex and generation roles and low rates of illegitimacy or divorce, were those established in the 1870s. There was also a more or less continuous decline in the crime rate through to the 1960s. European observers were impressed by what they called the "social peace" that reigned in Britain's industrial heartlands and outside the slums. It was often claimed that the policeman was regarded more as a figure of fun than of menace: think of the slow-witted plods of Agatha Christie or Dorothy Sayers, or the pedestrian decency of Britain's first television policeman, Jack Warner, in the series Dixon of Dock Green. The dominant trends in Britain during this period were the growth of a global market in food resulting in a cheap breakfast table, the crisis and decline of old staple industries (but well away from the Southeast), the depopulation of the countryside, and the retreat of the landed classes. These developments were accompanied by the continuous expansion of the urban and suburban populations, the growth of great retail chains, of holiday resorts, of the servant-less house and of increasingly homogeneous patterns of mass culture and mass leisure. Two world wars reinforced, but did not change the direction of change. Britain did not experience fascism or foreign occupation. Her industries were not dismantled or destroyed. There was no disruption in the functioning of British political institutions.

In some accounts, the period ending in 1960 is depicted as one of increasing individualism and pluralism. My own memory of growing up in the 1950s in the last phase of this epoch was less benign. When contrasted with today, my main recollection is of how repressive and conformist that culture was. Although there were instances of increasing freedom and individuality, particularly when looked at from the perspective of women's history, this was not my experience. In my memory, the 1950s were, if not the heyday, then at least the Indian summer of various forms of imperial and conservative collectivism: of the public school, clubland, the Season and Debs, the proliferation of old-boys' clubs, a renewed cult of monarchy, and of a variety of what historians have called "invented traditions." It was a period in which it was still true that, as Joseph Schumpeter had emphasised half a century before, empire provided the aristocracy with continued sources of power, wealth and prestige. ${ }^{2}$ Empire in turn reinforced cults of masculinity and muscular forms of virtue. It offered a space in which new forms of authoritarianism could flourish, whether in the school, the family, place of work, the regiment, or the sports field. 
After the Oscar Wilde trial in 1895 and into the 1950s, homosexuality had been forced back into the closet. Indeed, the beginnings of another Elizabethan Age were marked by a renewed campaign of prosecution of homosexuals at the time of the Coronation in 1953. The issue of divorce had forced the abdication of Edward VIII in 1938, as it had once wrecked the movement of Irish home rule during the Parnell divorce case; and even in the 1950s, the Queen's sister had not been permitted to marry a divorced man. A grisly series of hangings pronounced with relish by a sadistic Lord Chief Justice, Lord Goddard, and fully backed up by a succession of Conservative Home Secretaries, emphasised the centrality of capital punishment in the British system of justice. Corporal punishment was permitted both by the courts and the schools. Teenage or unmarried mothers could still be locked away. "Problem children" from the slums were still shipped out to the white dominions without redress; "mental defectives," a new coinage of this period, were without constitutional rights. A mix between empire and Darwinian ideas of evolution had produced brutal and authoritarian schemes in the name of race hygiene and imperial fitness.

A lot of these schemes did not come to pass, and I do not want to exaggerate their impact. I am simply trying to describe a world in which campaigns for different forms of modernisation made real sense. By modernisation I do not mean its present shrivelled and degraded meaning - the hectoring rhetoric of line management, relayed incessantly from the top downwards. What modernisation meant then was challenging the world of compulsory religion and compulsory cadet corps in the schools, of corporal punishment and capital punishment, of a set of repressive codes of governing morals, etiquette and dress. This was the atmosphere in which the year, 1956, marked some sort of change.

As I remarked at the beginning, I cannot really think the beginnings of my own interest in history, but I know that at the age of ten I could have told you all the kings and queens of England, France and the Holy Roman Empire, and I could have gone at least half way through the Pharaohs and the Roman emperors. I had an obsession with names, dates and lineages (not, of course, a sufficient basis of the historian's craft, but perhaps nevertheless one of its unregarded and rudimentary preconditions).

Where this preoccupation came from, I am not sure. But I connect it with my father's study. Both my parents lived in a world of books. My mother was - and still is - a voracious reader of novels. My father was a teacher of English literature and a would-be writer. He was an enthusiast of the eighteenth century and his hero was Dr. Johnson. But well before I became aware of his specific interests, the large collection of books in the study had become an object of fascination. Apart from dictionaries and encyclopaedias, book club editions, standard classics of English literature and children's books surviving from my parents' childhood, there was also a collection of old books, mostly dating back to the eighteenth century. In particular, there was a complete run of the London Magazine dating from the 1720s to the 1790s. Strange though it may sound, I greatly enjoyed reading these volumes, or at least sections of them, serialised from one 
number to another following the history of different countries. It connected up with my fascination with lineages and was reinforced by another old series, this time late Victorian, called Stories of the Nations, which I found in my school library. I was particularly intrigued by the Balkan states, Serbia, Bulgaria and Romania, and their emergence to "nationhood" through the struggle against the Turks.

My father had been born and brought up in South Wales. By tradition and repute, the Welsh, like the Scots (but unlike the English), have a reverence for learning and education; and that was certainly imparted to me. I remember around the age of twelve or thirteen, my father firing my curiosity with a passage from Charles Dickens's David Copperfield. It concerned the time in which the young David is housed with a very unpleasant stepfather called Mr. Murdstone who is a cold and gloomy evangelical. David's only solace is a bookshelf in his bedroom, containing volumes by Fielding, Smollett, Sterne and other eighteenth-century novelists. My father set me the task of reading these novels, which I did - most of them anyway. But my real enthusiasm, starting from that encounter, was for Dickens himself. Therefore, if I cannot quite answer the question why I became a historian, I can certainly explain why I became a nineteenth-century historian. Dickens inspired me, both with a visual sense of history, of crowded townscapes, peopled with an extraordinary array of individuals, each with their different private and idiosyncratic passions and preoccupations, and with a sense of history as moral drama - indeed, as melodrama - in which secret threads tie together in a common and unanticipated fate the otherwise unconnected lives of the lowly and the great. After Dickens, I never lost a sense of wonder about the modern city, as an immense and apparently private and anonymous artefact, whose subterranean rhythms, interconnections and meanings, the historian, like the novelist or the detective, could gradually bring to light.

At thirteen, I went to St Paul's School, which was - and still is - an academically high-achieving London public day school, once the Cathedral School, refounded by Dean Colet, a friend of Erasmus, and thus above all a school renowned in classics. Although I studied Latin and Greek, what then mattered most about the school was the impact made on me by two outstanding teachers, in history and in French.

The history master, Phillip Whitting, possessed an astonishing range of historical knowledge running from Byzantium to Frederick the Great. His "notes" were legendary, never what could be found in any textbook and a conception of history stuffed with unfamiliar stories and intriguing facts. I still, for instance, cannot think of Archbishop Laud without remembering his passion for "Cyprian Cats." Nor can I look at portraits of Richelieu without recalling his unremitting discomfort and the appalling stench attending his bodily presence. I do not know what Phillip Whitting's politics were. He was certainly not of the Left, but at school he enjoyed a subversive reputation in part because he made no secret of his lack of religious belief and in part because of his scepticism about the still-continuing efforts to prop up the British empire in Africa: "self-government," 
he insisted whenever this subject cropped up, "is always better than good government." One other cryptic clue I never followed up. I remember him encouraging me (without success) to study the four-volume edition of Vilfredo Pareto's Mind and Society, lodged in the school's history library.

The French master, F. S. Parker, was also acerbic about the present. But he not only kindled my enthusiasm for French literature from Molière to Proust. He also mapped out literary modernism as a corpus of literature which anyone with a claim to be educated should strive to master. Both these teachers and one or two of my school friends were important in my self-development, particularly after 1956 .

1956 marked a turning point. The Suez expedition and the uprising against the Soviet Union in Hungary made me seriously interested in politics. I joined the recently founded Campaign for Nuclear Disarmament and in the aftermath of Suez, protest and modernism seemed to come together. Each week, I lapped up the theatre criticism of Kenneth Tynan in the Observer, began to follow the new drama at the Royal Court, and read Freud's Psychopathology of Everyday Life. 1956 also witnessed the earliest portents of the youth culture which flowered in the 1960s. I can still remember my sense of liberation when I first exchanged my sports-jacket, cavalry twill trousers and cravat for a pair of American jeans; also how grateful I was to give up the unequal struggle to master waltz and quickstep, and to turn instead to "Blue Suede Shoes" and other new and amazing rock and roll numbers from the U.S.A., at that time only to be heard on café juke-boxes.

But it was France, not the U.S.A., which captured my intellectual interests. Inspired initially by my French teacher, I began to read French novels - Stendhal, Balzac, Flaubert, Proust, Gide; and I became interested in the Paris of Impressionism and art nouveau. This identification with things French was not original to myself. It was an expression of a still existent division between "athletes" and "aesthetes" that had originated in a minority disdain for the values of military and muscular Christianity practised by public schools from the 1870s through the 1960s. For me, it represented a sort of self-distancing from the English culture which I tried to depict at the beginning of this essay. One way of escaping the embrace of that culture was, as Richard Cobb once expressed it, to find a second identity: if not to pretend to be French, then at least to identify with French cultural tradition. ${ }^{3}$ In my case, even before I had begun to arrange my reactions into a selfconscious aesthetic stance, continental holidays had already led me to identify France with a certain style and sophistication wanting in the British. Nouvelle vague cinema a few years later only confirmed this sense of continental superiority in the art of living and the art of being grown up. Reading French history and literature deepened this identification and such was my enthusiasm that when I left school, I went to live and work for ten months in Paris. A family friend found me a job in Agence France Press. My hours of work ran from six to midnight. During the daytime, I began to read Sartre and Les Temps modernes, and haunted Chez Maurice, a café associated with the FLN's battle for Algerian independence, together with other young leftish bohemians from the United States and Germany. ${ }^{4}$ 
Around the time I left school, I had also become aware of the emergence of the New Left movement in England, which together with CND gave me a growing sense of a community of fellow spirits. Thus prepared, I went up to Oxford in October 1961, smoking Gitanes and immaculately dressed in the best that could be found on the rive gauche. My time in France reinforced in me a sense, shared by many of my friends in the early 1960s, of Britain as some sort of ancien régime presided over by a hereditary peer and still clinging to the decrepit trappings of Edwardian gentility. That was how the 1964 election was fought, the 14th Mr. Wilson against the 14th Earl of Home. Student radicalism - before Vietnam and the revolts of 1968 - was another expression of this optimistic push for modernisation at home, and abroad, peace, neutrality between East and West, and the development of the newly decolonised world.

My interests were primarily in this newly emerging post-imperial order and the first systematic writing about what was coming to be called the Third World. I became absorbed in the economics of development and took all the economic options that I could in my history finals. History, it then seemed to me, offered infinitely varied vistas of development and underdevelopment and of interconnections between economies and cultures. I also followed up these questions in the most exciting historical journals of the time, Annales and Past and Present. These preoccupations did not predispose me to take much interest in the local philosophical culture during my undergraduate years at Oxford, save for a brief enthusiasm for the philosophy of the late Wittgenstein inspired by Peter Winch's book, The Idea of a Social Science. ${ }^{5}$

As a research student, my fascination with the growth of third world cities led me to the economic and social development of eighteenth-and nineteenth-century London and Paris. Visually, I was inspired by the romantic visions of the street life of 1840s Paris found in Marcel Carne's Les Enfants du paradis, regularly put on around finals time at Oxford's La Scala cinema. At the suggestion either of Edward Thompson or of Richard Cobb, I also remember reading the classic pioneering study by Louis Chevalier, Classes laborieuses, classes dangereuses. ${ }^{6}$ It was one of the earliest inspirations of my approach to Victorian London. Like the historians of Annales and some economic historians in England, I was excited by the hidden regularities of weather, harvest and trade cycles as invisible constraints upon the worlds of politics and culture. For these reasons, I sought out as a supervisor the (then) professor of economic history, Hrothgar Habakkuk, who had written on the relationship between housing and migration cycles in the nineteenth-century Atlantic economy. ${ }^{7}$ For similar reasons, I was fascinated by Robin Matthews's study of the trade cycle in the 1830s and by the early work of Simon Kuznets on labour markets. ${ }^{8}$ This helps to explain my concentration upon the workings of the Victorian casual labour market in my doctoral dissertation, published as Outcast London in 1971.

My other reason for embarking upon this research topic was to answer a question about nineteenth-century political history. Why had the British electorate overwhelmingly voted for free trade in 1906, when sixty years earlier during the Chartist period, popular radicalism had apparently 
regarded free trade liberalism with such unequivocal hostility? In other words, how and why did liberalism become a popular cause? What accounted for the political and cultural shift that had occurred after 1850 ? It was to answer this question that I originally started out by planning a thesis around the success of the best-selling tract Self Help, by Samuel Smiles.

But once I embarked upon research, the primary material itself persuaded me that an enquiry into the success of Self Help would be less interesting than an exploration of those regions and occupations in the mid-Victorian economy in which its prescriptions failed to take root. Most notably, Victorian London and above all, the huge concentrations of under-employment, homework, casual labour, mendicancy and potential disorder referred to by mid-Victorian social observers and pamphleteers as "Outcast London." My book was organised around this contrast between the economic realities of the life of the London poor and the hopes and fears of politicians and social reformers.

Such a topic also gave me the excuse to live much of the time not in Oxford, but in London, which in the mid-1960s was a much more exciting place to be. After graduating, I had joined the editorial board of New Left Review, at that time a close circle of friends containing an extraordinary assemblage of talent. The Review's intimidating reputation for cleverness and intellectual seriousness was part of its attraction. For like the rest of my generation, I assumed that being intelligent and being on the Left were synonymous. (It was a real shock in the 1980s and 1990s to find that cleverness had apparently become a hallmark of the Right.) But most important was the fact that the Review's fame as an avant-garde political publication made it the first port of call for all the new ideas at that time springing forth from Europe and North America.

Of equal significance in my development as a historian was Nuffield College, Oxford, where I prepared my doctorate. At Nuffield, I met two anthropologists from France, Dan Sperber and Pierre Smith, both students of Claude Lévi-Strauss. Through them, I became familiar not only with the work of Lévi-Strauss, but also with the pioneering theory of Marcel Mauss on giit exchange. ${ }^{9}$ This interest in structuralist anthropology was to provide an important complement to my interest in economics. For it meant that alongside an economist's approach to casual labour, I could develop an anthropological conception of the perceived breakdown of relationships of charity in mid-and late-Victorian London.

The encounter with Lévi-Strauss was also important in changing my general conception of history. Until then, I had subscribed to a loose form of historicism, which I had identified with the essays of Lukacs or Sartre's Problem of Method, the introduction to his Critique of Dialectical Reason. ${ }^{10}$ I remember the excitement of reading Lévi-Strauss's attack on this approach, especially the last chapter of Pensée sauvage, demonstrating the arbitrariness of the historical teleology employed in Sartre's Critique. ${ }^{11}$ Predisposed by this prior grounding in structuralism, I became caught up in the excitement generated by Althusser's work, which appeared soon after. ${ }^{12}$ Like Lévi-Strauss, Althusser built his conception of history on an essay on differential time by the 
pre-eminent Annales historian Fernand Braudel (“La longue durée"). Historical time was not a unitary flow; rather there were different historical temporalities. What was exciting about this work from France was its attempt to get beyond the intellectually exhausted language of economic determinism and to redescribe a materialist conception of history in the language of psychoanalysis, linguistics, structural anthropology, the history of science, and the Annales. During these years - the mid- and late 1960s - the excitement of becoming acquainted with new theoretical developments in France - Lévi-Strauss, Braudel, Althusser, Barthes, Foucault, psychoanalysis and Lacan - quite eclipsed anything on offer locally. At the time, I thought we were witnessing an extraordinary period in the development of the human sciences; the challenge was to elaborate a conception of history, which took account of this transformation.

Among historians, my interest in French theory was probably exceptional, but my friends in Oxford and I all believed that we were pushing back the frontiers of history. If I had the fantasy that it was possible to construct some structuralist version of l'histoire totale, others were inspired by ideas of "history from below," of a quantitative approach to demographic history or the history of social structure, of the historical use of sociology or social anthropology, or of the pioneering of forms of oral history. All these different preoccupations went together under the vague but convenient term "social history" - a spectrum of methods and approaches united mainly by the common ambition to break out from the narrow confines of political and constitutional history. Around 1966, Raphael Samuel, Tim Mason and I set up a Social History Seminar, in which these aspirations were expressed. It met intermittently for around four years at St Anthony's College.

Our ambitions were not confined to the sphere of higher research. These were also the years of the first History Workshops, organised by Raphael Samuel and the history students of Ruskin College, Oxford - events in which we all participated. Ruskin was a college largely supported by the trade unions and intended for mature students who had left school at the age of fifteen without formal educational qualifications. The workshops were innovatory in two ways. Firstly, in form: professional historians from Oxford and elsewhere shared platforms with Ruskin historians who presented research papers - some of which were quite as compelling as those delivered by the established academics. Secondly, in content: historical questions raised by the women's movement, by discrimination and racial tensions, by the desires of children, were discussed earlier in these meetings than elsewhere in Britain; and even the supposedly predictable issues of labour history assumed unfamiliar shapes once encompassed within the broader subject matter of popular culture or subjected to the anti-authoritarian questioning of the 1960s.

Some of the components of my revised conception of history were visible in an essay written in 1967 in New Left Review. ${ }^{13}$ I find it a difficult essay to re-read, not only because of its arrogant style, but also because of the substance of its argument, which I had completely forgotten. The dominant theme of the essay clearly derived from what was then a shared Review position. This 
was that the defect of English history writing had been its lack of contact with a classical sociological tradition comparable to that represented in Germany by Max Weber. Such an argument had formed part of the Review's aggressive diagnosis of the malaise of English culture. English letters had lacked a Marx or a Weber; it was still tied to an empiricist and theoretically impoverished intellectual lineage that had started with Locke and ended with the intellectual and political complacency of 1950s 0xford philosophy.

The stronger and more distinctive part of the essay contained a discussion of the famous lectures of E. H. Carr, What is History ? $^{14}$ Carr's argument boiled down to two points: one, that in order to understand history, it was necessary to understand the historian - a position sanctioning extreme relativism; and two, that the more sociological history became, the better. In response I argued, first, that it was time to move on from the standard English debate about fact and value; and I used examples from Marc Bloch, Braudel, Lévi-Strauss and Althusser to argue that what really mattered was the construction of new historical concepts.

My qualified endorsement of Carr's second point requires some explanation. For in Britain at least, it is now difficult to recall the hopes then invested in a theoretically informed historical sociology, since no tradition of enquiry comparable to that generated by Barrington Moore and Theda Skocpol in United States, Bourdieu in France or Habermas or Koselleck in Germany subsequently developed. ${ }^{15}$ In recent years, some important works of historical sociology have been produced - those of Robin Blackburn on slavery and Garry Runciman on twentieth-century Britain are outstanding. ${ }^{16}$ But what has been accomplished in Britain has largely been the achievement of a few isolated individuals working outside any institutional context. As disciplines, the preoccupations of historians are even further apart from those of sociologists than they were in the $1960 \mathrm{~s}$.

In retrospect, it is not difficult to see that there was something unbalanced about the judgements put forward in this essay. In Britain, there had been an outstanding tradition of empirical social investigation starting in the nineteenth century (the parliamentary "blue books," the investigations of the statistical societies, Henry Mayhew, Charles Booth, Sidney and Beatrice Webb) and I put that tradition to use in Outcast London. Second, in the light of my more recent interest in intellectual history, it seems extraordinary, that in order to reach its conclusion, the essay passed over unnoticed the conjectural history and political economy developed in eighteenth-century Scotland - traditions of discourse constitutive of all modern histories of society. I also find it strange that the lack of a Weber could be decried without any reference to the unstable and authoritarian Wilhelmine culture of which he was a product. A few years later, my quest for a theoretically more illuminating way of engaging with politics and the history of ideas led me almost to abandon the sociological terrain altogether. But even before then, as I argued in an essay in 1976, I had turned strongly against the idea that the theoretical deficiencies of British history could be remedied by resorting to sociology. ${ }^{17}$ 
I have dwelt on this essay partly because it recalls my conception of history 1967, but also because it indicates the deep impression made upon my thinking by those battles over the relationship between history and theory that were at their most intense between the mid-1960s and the late 1970s. But in order to explain my own position during these years, it is necessary first to say something about the conflict, of which I became a part.

The basic tension was between two forms of radicalism: the new radicalism of the 1960s and an older radicalism originally occasioned by the Communist Party's Popular Front strategy during the 1930s, but primarily inspired by the upsurge of Left democratic populism during the Second World War. ${ }^{18}$ This older tradition - what I have called Anglo-Marxism - pre-eminently, the work in history of Rodney Hilton, Christopher Hill and Edward Thompson, and in cultural criticism of Raymond Williams - had truly come into its own after 1956 when the need to break with a Stalinist past had led the historians to emphasise even more insistently the strength of an indigenous radical inheritance. ${ }^{19}$ They had built upon and refashioned strong native traditions of puritan and dissenting conceptions of "the people" in a story of England's progress from the Peasants' Revolt through the seventeenth-century revolution to the nineteenth-century onset of industrial capitalism and the "making of the English working class." In adopting this approach and drawing so eloquently upon the array of primary texts from John Ball through the Putney debates to William Blake and Thomas Paine and finally to William Morris, they could not but renew the unique and paradigmatic status originally ascribed to English history as the chosen Protestant people. It was that approach which helped to explain the apparent ease with which this idiosyncratic form of Marxism had become grafted onto the main stem of English radical-liberal historiography, descending from the 1870s through the writing of J. R. Green, Thorold Rogers, Arnold Toynbee, Noel Brailsford, the Hammonds and R. H. Tawney.

Both the strengths and the weaknesses of this Anglo-Marxist interpretation of history derived from the insularity of its development. In the case of Williams and Thompson, this insularity had been further reinforced, while students in Cambridge, by the impact of the cultural criticism of $F$. R. Leavis, which drew upon the same puritan stock. Anglo-Marxism, like the larger political culture of which it was a part, had been untroubled by wartime defeat, by the collapse of the state, by the reality of revolution or the consolidation of a one-party state. It was another example of what was argued at the beginning of this essay: that the point of crisis and disintegration of the cultural and political attitudes which had characterised late Victorian or Edwardian Britain whether on the Left or on the Right - occurred in the 1960s and its aftermath.

The group's members, whom I joined in 1964 and who had taken over the Review two years before, were not products of the struggle against fascism, of the Popular Front or of the Second World War, but of the post-imperial and non-communist radicalism of the years after 1956. It was a group interested in continental philosophical traditions, in the novel use of concepts and in making a break with the inherited verities of Anglo-Saxon culture, whether of Right or Left. The aim 
of the Review, like much of the new radicalism of the 1960s, was to make an abrupt break with the past. In the early essays of Perry Anderson and Tom Nairn, this meant raising comparative questions hitherto virtually absent from English radical historiography. It also meant introducing an English-speaking audience to the crisis-driven career of European philosophy between the 1920s and 1950s and what New Left Review later called Western Marxism. This brutal comparative approach produced exasperation among those writing from an Anglo-Marxist perspective. Unspoken assumptions about England's status, clothed in Marxist terminology, but inherited from a Whig and Protestant past, were subjected to unsentimental scrutiny. Edward Thompson led the Anglo-Marxist riposte in a famous essay called "The Peculiarities of the English." It signalled a growing divide between the "old" and "new" New Left.

During the 1960s and 1970s, I did not feel comfortable with either of these positions. My own historical work during the 1960s and 1970s was closer to that of Eric Hobsbawm, with whom I became a good friend. Although often grouped with the Anglo-Marxists, his interests and starting point were quite distinct. His Marxism was the product of his schoolboy experiences in Vienna and Berlin. In England, he expressed great respect for the early Fabians and like them was an admirer of the homegrown constitutionalism and rough-hewn economics of the British trade unions. His interest in economic history was inspired by Michael Postan and Maurice Dobb. His early ambition, both as a communist and as a historian, was to answer the magisterially "optimistic" Economic History of Modern Britain written by the Cambridge historian, Sir John Clapham. ${ }^{20}$ But his interests were never confined to Britain or even to Europe. His work on Primitive Rebels from Peru to Sicily and the Balkans was almost global in scope, just as - while focusing primarily on modern history - he was quite prepared to present findings on "the general crisis of the seventeenth century" or write up his enthusiasm for the development of twentiethcentury jazz. ${ }^{21}$ Here was a historian equally at ease in the Ecole des Hautes Etudes in Paris, in Bielefeld, Buenos Aires, or in later years, in the New School for Social Research in New York. I by no means agreed with everything that Eric wrote or said - nor do I today. But what has been truly remarkable has been the consistency and professionalism of his intelligence throughout his work. Here then, was the model of how an internationally known comparative historian should be, a model which we could only aspire to emulate from afar.

My relationship with Anglo-Marxism was more complicated. As a historian, I admired the pioneering historical research of those working within this tradition. At school, I had been a strong admirer of the writings of Christopher Hill on the English Civil War. ${ }^{22}$ From 1963, I became a close friend of Edward and Dorothy Thompson. I was enthusiastic about Edward's new work on the eighteenth century and Dorothy's researches on Chartism. When I worked on Outcast London, I greatly benefited from Edward's enormous knowledge of late-Victorian English socialism and utopianism amassed during his research on William Morris, just as I later built on Dorothy's pioneering work on Chartism. ${ }^{23}$ However heated the disagreements, whether about the Review or 
eighteenth-century "wife sales" as the poor man's divorce, it was always a pleasure to visit the Thompsons in Halifax or Snowdonia, Leamington Spa or Worcester. The basis of disagreement remained fairly constant, even when not explicitly stated. I was never enthusiastic about Thompson's idea of "history from below" or about his attacks upon the "condescension" of historians and did my best to counter his suspicions about continental theory.

I also felt an instinctive antipathy towards a peculiarly English form of moralism, present in AngloMarxism and associated particularly with Leavis and his followers. A visceral puritan and the heir to a tradition of romantic cultural criticism, Leavis had followed Matthew Arnold in his belief that great literature possessed a civilising and educative function and furnished the heart and mind with the moral and cultural discriminations once found within religion. His politics had been a crusade against the Bloomsbury group, which he alleged was a self-regarding metropolitan literary clique who dominated official culture. In literary criticism, his hero had been D. H. Lawrence. He had dismissed most of Dickens as morally frivolous and unfitting for a place within his own "great tradition." 24

My own views, both in style and substance, clashed with this Leavisite stance at almost every point. To my early love of Dickens, school had added an identification with French literature and art nouveau. At Oxford, as I had stated in the undergraduate newspaper, Cherwell, my socialism was that of Oscar Wilde in his "Soul of Man Under Socialism." My sympathies were therefore with Bloomsbury. It was Bloomsbury which had nurtured an avant-garde, had pioneered modern art, had translated Freud, had championed feminism and had both defended and lived out sexual freedom. Whatever their shortcomings, their vision had been far preferable to the militant and self-righteous provincialism of Leavis and his disciples.

To this inheritance, I should also add the profound and immediate impact made upon me from the late 1960s by the women's liberation movement. Not only did it change the way in which I thought I ought to live, it also put under critical scrutiny all inherited radical and socialist assumptions, both the verities of political practice and - especially relevant to my closest companions and friends - how the subject matter of history was to be conceived, not least the question of class.

This new form of feminism separated me as much from the predominant position of the Review, as it did from the assumptions of the old New Left. It also put into a different perspective the revolutionary leftist fantasies that came to the fore around 1968. Therefore, although I strongly supported the Review's modernism, endorsed its criticism of empiricism and shared its curiosity about the traditions of Western Marxism, I came to see that I did not fully agree with its implicit politics. Like many others in the 1960s, I had read the works of Isaac Deutscher and invested the storming of the Winter Palace in 1917 with a halo of romance.$^{25}$ But unlike some on the Review, I had never believed that Bolshevism or the Russian Revolution had relevance to the question of socialism in Britain or Western Europe. I therefore could not take seriously the politics of 
revolutionary sects or the furtive mandarin Leninism that increasingly informed the perspectives of the Review. In the mid-1960s, these differences were unimportant, but in the years after 1968 they produced an increasing divide.

From the beginning, I had wanted to build bridges between the old and the new New Left. But it was only in the early 1970 s that this ambition began to manifest itself in my work. Strangely perhaps, I had not read through The Making of the English Working Class when it first appeared. ${ }^{26}$ It was only during the early 1970s that I seriously studied Edward's book. It was also during these five or six years following the publication of Outcast London in 1971, that for the first time I studied Marx. My ambition was to recast the "materialist conception of history" in French poststructuralist terms. On the basis of new work in social history and my own researches on London, I attempted to produce an alternative to the standard assumptions of British labour history passed down from Engels and the Webbs. In a series of essays written in the early 1970 s, I attempted to develop a new approach to the question of the decline of radicalism and social confrontation in the post-Chartist period. ${ }^{27}$ My aim was to replace the old theory of a labour aristocracy by an interpretation that emphasised the general stabilisation of relations between wage earners, employers and government. I also added a cultural dimension to the argument. I started from the apparent contrast between the radical popular culture of the early nineteenth century depicted in Edward Thompson's Making of the English Working Class and the conservative and defensive culture described in The Uses of Literacy, Richard Hoggart's classic account of growing up in working-class Leeds in the 1930 s. $^{28}$ Why did "the working class" whose "making" was depicted in Thompson's book bear so little resemblance to that familiar to historians and sociologists in the twentieth century? I attempted to answer this question by exploring what I thought was a conservative shift in the development of popular culture in London during the Victorian period. In an ironical tribute to Edward Thompson's book, I described the process as "a remaking of the working class." 29

Thompson's 1978 polemic against Althusser in The Poverty of Theory, the last of the culturalpolitical battles that accompanied my apprenticeship as a historian, seemed to me a polemic stuck in the years before $1956 .^{30}$ For me, the interest of reading Althusser and other French theorists had little to do with politics. It had been a way into philosophy. It had introduced me to a whole range of unfamiliar theories and concepts and a whole spectrum of unfamiliar thinkers from Spinoza to Bachelard. If Edward Thompson wished (yet again) to settle accounts with Stalinism, Althusser was an inappropriate target. Similarly, the applause Thompson gained for his polemic was not primarily political. It came from those afraid of systematic philosophy in any form. In my case, questions provoked by the work of Lévi-Strauss, Barthes, Althusser and Lacan pushed me towards a more explicit theoretical engagement with the status of language and discourse in history, and finally - in the late 1970s - beyond a Marxian paradigm altogether. 
By the late 1970s, for others too, the time for these battles between history and theory had all but passed. The May 1968 events had created the real parting of the ways. Thereafter, politically, the French theorists became increasingly unhinged. Foucault called for a prisoners' revolt. André Glucksmann, soon after to become one of France's "new philosophers," called for another Resistance against the Occupation of France. Althusser's writings zig-zagged between a crude agitprop Leninism and a rudderless liberalism. In Britain also, the 1968 events had produced a recrudescence of Marxist groupings, intent on direct action or revolutionary organisation.

These were readings of the times and forms of politics from which I strongly dissented. 1968 certainly made me more curious about the foundations of Marx's theories of history and politics. But politically, what impressed me most about Britain around the end of the 1960s were not the politics of the student revolt (a fairly tame affair) or even of the protest movement against American action in Vietnam (however impressive). It was rather the unapologetic racism of the Smithfield meat porters marching in 1967 in support of Enoch Powell, the gerrymandered Protestant state of Northern Ireland, the degradation of London's (women) night cleaners and the uphill battle to help them form a trade union, and the pious voyeurism annually solemnified in the coronation of Miss World. My commitment, therefore, was to a politics of enlightenment and proselytisation, and for that reason I joined with others in an attempt to establish a non-aligned radical weekly.

In the midst of this activity in the early 1970s, I left England for Frankfurt to begin research on the life and thought of Frederick Engels. I had decided to undertake this project, in part because I was anxious not to become too specialised as an English historian, in part because Engels' life and writings raised central issues in the understanding of the nineteenth century. It proved a good choice. For working on or around Engels proved more fruitful than I could have imagined. At the time, it was an apt way of setting my experience of the politics of the 1960 s within a larger historical framework. But it also proved an excellent point from which to reassess the political development of the nineteenth and twentieth centuries. Detailed research on Engels' political and philosophical development suggested the need, first to rethink the interpretation of radicalism and Chartism, and ultimately to reconsider the historical significance of socialism as a whole.

My distaste for groupuscule revolutionary politics was further enhanced by living in Frankfurt at a time when the Red Army Faction exercised a considerable sway over the local Left. Their presence meant that even those who disagreed with the politics of revolutionary terror became reluctant to condemn it and unwilling to defend the democratic constitution of the Federal Republic. I became more than ever convinced that revolutionary and extra-parliamentary politics in Western Europe were intellectually frivolous and politically counter-productive.

When I returned to England, I therefore decided to concentrate my practical energies within the sphere of history. The most positive aspect of the student radicalism of 1968 had been its criticism of the conventional assumptions informing particular academic disciplines and its ambition 
to pioneer new areas and forms of enquiry, often outside and beyond the academy. It was with the intention of breaking down these distinctions between lay and professional history, that together with Raphael Samuel, Sally Alexander, Anna Davin and Tim Mason, we founded the History Workshop Journal in 1975. History Workshop Journal still flourishes today. Perhaps its most important characteristic is the pluralism that was built into it from the start. As Raphael Samuel insisted from the beginning, the journal should speak through many voices. This flexibility, in which the radicalism of the journal was identified with its experimental character, was to prove its salvation in negotiating the changes in political climate, conceptions of history and cultural ethos which have occurred over the more than twenty-five years since its foundation.

In the first few years of the History Workshop Journal, the battle about theory rumbled on, culminating in a large and bad-tempered History Workshop held in Oxford in 1979. Nothing ends neatly, but this conference more or less brought these debates to a conclusion. Thereafter, the pressure of external events increasingly pushed such discussion to the sidelines. 1979 was the first year of Mrs Thatcher's government, followed soon after by the triumph of Ronald Reagan in United States and a renewal of the Cold War antagonisms. Domestically, Mrs Thatcher's government launched an uncompromising counter-offensive against all the gains made by organised labour in the 1960s and 1970s. This provoked the disastrous miners' strike of 1984 and the disintegration of the politics of organised labour as it had developed since the Second World War.

But in the 1970s there had also emerged more positive reasons for redefining the content and direction of historiographical debate. The growth of the women's movement, accompanied by the emergence of a feminist perspective on history, created growing interest in forms of experience that could not be adequately recounted in the categories employed in Anglo-Marxist social history or New Left theory. It raised increasing doubts about the explanatory value of class and the historical narrative built upon it. Furthermore, while feminism raised uncomfortable questions about who was included within particular historical narratives and upon what terms, literary theorists, starting with Hayden White, had begun to raise questions about the tropes underlying the construction of historical narrative and to dramatise history as a form of literary artifice. ${ }^{31}$ The usefulness of such questioning was underlined by the local findings of social and labour historians themselves, who without any settled intention to do so, cleared away or undermined one after another of the cherished milestones of a heroic Popular Front history of the people.

I drew upon all these developments in 1982 in the new linguistically oriented essays I wrote for Languages of Class. My book attacked the assumptions informing social history and AngloMarxism. But my case was no longer made in the name of a new theoretical doctrine from the Continent. Languages of Class did not focus solely upon theoretical criticism; nor did it renounce the explanatory value of history itself. Instead, the book challenged existing historical interpretation by beginning to tell a different and more probable story about the nineteenth century and the constitution of the modern world. 
I have attempted to describe my apprenticeship as a historian by relating it to the political and theoretical conflicts generated by the arrival in Britain of new and radical philosophies in the 1960s and 1970s. Looking back at that period now, it is not difficult to see that some of those new theories, which I made such strenuous efforts to master, were at least as one-sided as the ones I strove to reject. There is no need today to rehearse the flaws of structuralism. I would only say that it was through these preliminary theoretical encounters (and the pedantry which so often seems to attend initial attempts to master systematic forms of theory), I was eventually able to find my own voice.

More specifically, working through those theoretical positions provided an invaluable preparation for my subsequent work. It got me beyond the English historian's timidity about concepts and systematic forms of thought, which can be tedious, but also beyond the devotee's fetishisation of theory, which can be even worse. Once I had abandoned a Marxian paradigm and had become convinced of the central importance of language and discourse in the construction of politics, my next step was to employ these insights in an investigation of the genealogy of the explanatory schemas that purported to define the modern world. My general interest in the world since the eighteenth century and my particular research on Engels led me to focus upon two of these schemas, which played crucial roles in framing the political and social understanding of the modern world. The first was the notion of commercial society, later political economy. The second was that which within the Marxist tradition had purported to be its antagonistic other, socialism. If the Marxian paradigm no longer explained the world, what explained the formation of this paradigm and its extraordinary impact upon the world?

On the question of the origin and development of the notion of "commercial society," I was enabled to inaugurate a research project on the history of political economy at the Research Centre of King's College, Cambridge. Its aim was to initiate a different approach to the history of economic ideas. The goal was to create a history that avoided the competing teleologies, positivist or Marxist, classically elaborated in Marx's Theories of Surplus Value and Schumpeter's History of Economic Analysis. ${ }^{32}$ The first fruits of that enquiry were published in 1982, in a collaborative volume edited by Istvan Hont and Michael Ignatieff, Wealth and Virtue.

In this enquiry, I found many points of convergence between my own approach and that of the study of intellectual history and the history of political thought, as they had developed in England and especially in Cambridge from the 1960s. But the focus of this work had been almost exclusively upon liberal and republican thought, and it had been concentrated to a disproportionate extent on an earlier period, running from Machiavelli to Locke. The growth of a modern economy, the transition from confessional to post-confessional state, the late eighteenth-century mobilisation of a vastly enlarged political nation and the genesis of socialism had received almost no attention. These were also themes that did not appear to fit comfortably an agenda largely designed for the early modern period and paying comparatively little attention to religious or economic thought. ${ }^{33}$ 
By contrast, my own work became increasingly preoccupied with the threads that tied together religious and economic criticism. The centrality of such interconnections could hardly be missed by anyone studying Hegel or Marx's early writings. But they also played a significant part in the political theories thrown up by rational dissent or the disagreements about the millennium among political economists and socialists in Britain, or in the discussion of Industrie or "the new Christianity" in post-revolutionary France. The work of Miri Rubin on the increasing centrality of the Eucharist and of the intercessory role of the priest in the two centuries before the Reformation not only provided a more precise historical framework in which to examine the longue durée of interconnection between political and religious belief. ${ }^{34}$ It also further underlined - from the early Church fathers onwards - the interweaving of Christian and classical sources in the crystallisation of political philosophies which came to map out the modern world in the aftermath of the French Revolution.

In 1992, the opportunity of bringing together economic, political and intellectual history arose again, when Emma Rothschild and I established in Cambridge the Centre for History and Economics. Our aim was to intervene both in historical and contemporary debate. Methodologically, our goal was to avoid the usual connotations of the word interdisciplinary. We wished to encourage, not an overlap between what was marginal to history and what was marginal to economics but rather, creative tension between the intellectual core of each discipline. But even more important was our substantive project: to encourage both historians and economists to go back to the late Enlightenment and get behind the distinctions between collectivism and libertarianism, socialism and liberalism which have dominated the intellectual and political history of the last two hundred and fifty years. Emma's work has focused upon the complexity of motivation evident in the study of "economic" and other forms of behaviour in the work of Adam Smith, and in the revolutionary reform proposals of Condorcet. ${ }^{35}$

My own work has focused upon the period beginning around the end of the Seven Years War. Its aim has been to construct an alternative history of the emergence of new systems of thought at the end of the eighteenth century, later called "socialist." The standard interpretations of G. D. H. Cole, Jacques Droz and George Lichtheim ascribed the emergence of socialism to the combined effect of the industrial revolution, the emergence of the industrial proletariat and the egalitarian legacy of the French Revolution. Such an approach largely accepted the positions first put forward by Marx and Engels in The Communist Manifesto, Socialism: Utopian and Scientific, and other writings.

If, as I had argued in Languages of Class, a discursive approach undermined the validity of the social interpretation of Chartism and the movement from "utopian" to "scientific" socialism, there remained the problem of providing an alternative historical explanation for the emergence and growth of a movement of the global magnitude of socialism. My work elaborates such an explanation, which will appear in forthcoming publications. Notably, Before God Died, The Rise 
and Fall of the Socialist Utopia (not yet published, but already delivered in a preliminary form as the Carlyle Lectures in Oxford in 1997); and The Communist Manifesto (a new critically annotated edition with a book-length introduction to be published as a Penguin Classic in 2002). In Before God Died, I concentrate upon the crisis in Christianity occasioned by the last phase of the Enlightenment and the French Revolution in France, Germany and Britain. In Britain, I draw attention to the proximity between the scientific and millennial claims of Owenism and to the original identity between the terms "socialism" and "social science." Overall, I centre my interpretation upon the impact of the French Revolution. In contrast to the old Marxisante social interpretation and the alternative political interpretation put forward by Furet, I stress the centrality of the revolution's attempt, first to reform the Church, and then to replace Christianity. What became "socialism," I argue, dated from the period of Thermidor (1795-1802) and began life as a search for a new "scientific" form of the pouvoir spirituel once possessed by the Catholic Church. My examination of the works and preoccupations of the "utopian socialists" situates the genesis of "socialism" both in France and Britain in the claims of new, "scientific," postChristian religions. Conversely, fundamental economic criticism of the emerging shape of a global commercial society and of the new mechanised forms of production was largely the work of liberals and republicans.

In my work on the "communism" of The Communist Manifesto, I emphasise the importance of the legal and historical debate about forms of property in the fifty years after the French Revolution. I examine the relevance of conjectural histories of property found in the natural law tradition and in political economy, and I emphasise the central importance of the German historical school of law in deciphering and revealing the ubiquity of communal forms of possession in ancient societies and the vulnerability of transhistorical assumptions (enunciated in the Code Napoleon) about the naturalness of private property. Crucial also to Marxian communism, as it had been already to 0 wenite socialism, was the prospect of a society beyond scarcity. This was the novel possibility, first glimpsed in the 1790s in the confrontation between Godwin, Condorcet and Malthus. In Marx's hands, this prospect took the form of a society based upon the satisfaction of need rather than the allocation of scarce resources; and, therefore, of a society which did not require private property, religion, ethics, justice or political authority. By revealing the different intellectual components briefly and precariously brought together in the Manifesto, I hope to situate the place of Marx's communism in the history of Western thought.

Studying the intellectual history of Europe during the French Revolution and its aftermath - of the birth of "social science," of German idealism and the historical school of law, of Hegel, the Young Hegelians and Marx, of British Romanticism from Coleridge to Carlyle, of philosophic radicalism and early socialism and so on - has an enormous intrinsic interest. But this work is also relevant to current political conflict. Not only does it reveal the submerged foundations of so many of the theoretical positions I naivvely tried to engage in the 1960s and 1970s, it also suggests alternative possibilities for the future. If, for example, the most lasting criticisms of a global commercial 
society or of the world market were first voiced by those later classified as "liberals" or "republicans," and if the most distinctive contribution of socialism had been the addition of cosmopolitan, providential and quasi-religious dimensions to economic criticisms derived from elsewhere, this makes possible a more constructive assessment of the decline of socialism. It suggests new starting points in the criticism of global commercial society, unburdened by fantasies about the total abolition of markets, delusions about class, utopian aversion to pluralism or socialist predilections for the authoritarian state. Like Emma Rothschild's work on economic sentiments, such a starting point might enable the friends of progress to get away from the current Left's indiscriminate excoriation of the Enlightenment and instead to build once again upon Enlightenment foundations in forming new kinds of alliance against the same age-old sources of greed, exploitation and misery. In these ways, it seems to me that compared with thirty years ago, the historian can make a perhaps less grandiose, but more helpful contribution to the battles of the present. 
${ }^{1}$ A powerful case for the early 1960 s as a fundamental turning point is made in José Harris, Private Lives, Public Spirit. A Social History of Britain 1870-1914. Oxford: Oxford University Press, 1993.

${ }^{2}$ Joseph. A. Schumpeter, Imperialism. Social Classes. New York: Meridian, 1955.

${ }^{3}$ See Richard C. Cobb, A Second Identity. Essays on France and French History. London: Oxford University Press, 1969.

${ }^{4}$ I read Sartre's essays in Les Temps modernes. They were later translated into English as The Problem of Method. London: Methuen, 1964.

${ }^{5}$ See Peter Winch, The Idea of a Social Science and its Relation to Philosophy. London: Routledge 1958.

${ }^{6}$ Louis Chevalier, Classes laborieuses et classes dangereuses à Paris pendant la première moitié du XIXe siècle. Paris: Plon, 1958.

${ }^{7}$ Hrothgar John Habakkuk, "Fluctuations in House Building in Britain and the United States in the Nineteenth Century," Journal of Economic History, 22 (1962), pp.198-230; and see also idem, American and British Technology in the Nineteenth Century. The Search for Labour-Saving Inventions. Cambridge: Cambridge University Press, 1962.

${ }^{8}$ R. C. 0. Matthews, A Study in Trade Cycle History. Economic Fluctuations in Great Britain, 1833-42. Cambridge: Cambridge University Press, 1954; Simon Smith Kuznets, Seasonal Variations in Industry and Trade. New York: National Bureau of Economic Research, 1933.

${ }^{9}$ Marcel Mauss, The Gift. London: Cohen and West, 1954.

${ }^{10}$ Jean-Paul Sartre, Problem of Method; Georg Lukacs, History and Class Consciousness, London: Verso, 1970.

${ }^{11}$ Claude Lévi-Strauss, Pensée sauvage. Paris: Plon, 1962, ch. ix.

${ }^{12}$ See Louis Althusser, Pour Marx. Paris: Editions la Découverte, 1966

${ }^{13}$ Gareth Stedman Jones, "History: the Poverty of Empiricism," New Left Review, 46 (1967), pp. 29-43.

${ }^{14}$ Edward Hallett Carr, What is History? London: Macmillan, 1961.

${ }^{15}$ See Barrington Moore, Social Origins of Dictatorship and Democracy. Lord and Peasant in the Making of the Modern World. Boston: Beacon Press, 1967; Theda Skocpol, States and Social Revolutions. A Comparative Analysis of France, Russia, and China. Cambridge: Cambridge University Press, 1979; Pierre Bourdieu, Homo academicus. Paris: Editions de Minuit, 1984; idem, La Noblesse d'état. Grandes écoles et esprit de corps. Paris: Editions de Minuit, 1989; Jürgen Habermas, The Structural Transformation of the Public Sphere. An Inquiry into a Category of Bourgeois Society [1962]. Cambridge: Polity Press, 1989; Reinhart Koselleck, Critique and Crisis. Enlightenment and the Pathogenesis of Modern Society. Cambridge, MA: MIT Press, 1988; Otto Brunner, Werner Conze and Reinhart Koselleck (eds.), Geschichtliche Grundbegriffe. Historisches Lexikon zur politisch-sozialen Sprache in Deutschland. 8 vols. Stuttgart: KlettCotta, 1972-1997.

${ }^{16}$ Robin Blackburn, The Overthrow of Colonial Slavery 1776-1848. London: Verso, 1988; W. G. Runciman, A Treatise on Social Theory. Vol.3: Applied Social Theory. Cambridge: Cambridge University Press, 1997.

${ }^{17}$ Gareth Stedman Jones, "From Historical Sociology to Theoretic History," British Journal of Sociology, 27 (1976), pp. 295-306.

${ }^{18}$ See George Orwell, "The lion and the Unicorn," in Penguin Essays of George Orwell. London: Penguin, 1968, pp.144-94; George D. H. Cole and Raymond Postgate, The Common People 1746-1946. London: Methuen, 1946 (first edition 1938). 
${ }^{19}$ See Gareth Stedman Jones, "Anglo-Marxism, Neo-Marxism and the Discursive Approach to History," in Alf Lüdtke (ed.), Was bleibt von marxistischen Perspektiven in der Geschichtsforschung? Göttingen: Vandenhoeck und Ruprecht, 1996, pp. 149-209.

${ }^{20}$ See John Harold Clapham, An Economic History of Modern Britain. 3 vols. Cambridge: Cambridge University Press, 1926-38. For Hobsbawm's rejoinder to Clapham, see "The British Standard of Living 17901850," Economic History Review, 10 (1957-58), pp. 46-68.

${ }^{21}$ Eric Hobsbawm's historical output has been immense. But the two works which made the deepest impression upon me were Primitive Rebels (Manchester: Manchester University Press, 1959) and Labouring Men. Studies in the History of Labour (London: Weidenfield and Nicolson, 1964).

${ }^{22}$ In particular a collection of his essays, which I read at school. See Christopher Hill, Puritanism and Revolution. Studies in Interpretation of the English Revolution of the 17th Century. London: Secker and Warburg, 1958.

${ }^{23}$ See E. P. Thompson, Whigs and Hunters: The Origin of the Black Act. London: Lane, 1975; idem, Customs in Common. London: Merlin Press, 1991; Dorothy Thompson (ed.), The Early Chartists. London: Macmillan 1971; The Chartists. Popular Politics in the Industrial Revolution. London: Temple Smith, 1984.

${ }^{24}$ See Frank R. Leavis, The Great Tradition. George Eliot, Henry James, Joseph Conrad. London: Chatto and Windus, 1948.

${ }^{25}$ See Isaac Deutscher, The Prophet Armed. Trotsky 1879-1921. Oxford: Oxford University Press, 1954; idem, The Unfinished Revolution: Russia 1917-1967. London: Oxford University Press, 1967.

${ }^{26}$ E. P. Thompson, The Making of the English Working Class. London: Gollancz, 1963.

${ }^{27}$ See chapters 1, 2 and 4 of Gareth Stedman Jones, Languages of Class. Cambridge: Cambridge University Press, 1982.

${ }^{28}$ Richard Hoggart, The Uses of Literacy, London: Chatto and Windus 1957.

${ }^{29}$ See Languages of Class, ch. 4.

${ }^{30}$ E. P. Thompson, The Poverty of Theory and other Essays. London: Merlin Press, 1978.

${ }^{31}$ See Hayden White, Tropics of Discourse. Essays in Cultural Criticism. Baltimore: Johns Hopkins University Press, 1978; Metahistory. Six Critiques. Middletown, CT: Wesleyan University Press, 1980.

${ }^{32}$ See Karl Marx, "Theories of Surplus Value," in Karl Marx and Frederick Engels, Collected Works. Vols. 324. London: Lawrence and Wishart, 1975; Joseph A. Schumpeter, History of Economic Analysis. New York: Oxford University Press, 1954.

${ }^{33}$ This was particularly surprising since the main point of one of the most important works on the history of political thought to come out of Cambridge, John Dunn's, The Political Thought of John Locke (Cambridge: Cambridge University Press, 1969), was that Locke's political thought made little sense outside a theistic framework.

${ }^{34}$ Miri Rubin, Corpus Christi. The Eucharist in Late Medieval Culture. Cambridge: Cambridge University Press, 1991.

${ }^{35}$ See Emma Rothschild, Economic Sentiments. Adam Smith, Condorcet and the Enlightenment. Cambridge, MA: Harvard University Press, 2001. 